\title{
ENERGY SAVING AS A PRIORITY DIRECTION OF STATE POLICY IN UKRAINE AND IN THE WORLD: PROBLEMS OF USING SOLAR ENERGY IN ARCHITECTURE
}

${ }^{1}$ Ermakova S.S., Doctor of Pedagogical Sciences, Professor, ermakova.s2011@yandex.ua, ORCID: 0000-0001-9524-518X

${ }^{1}$ Vasylenko O.B., Doctor of Arch, Professor, abvasilenko10@gmail.com, ORCID: 0000-0002-8261-3104

${ }^{1}$ Al Echcheikh El Alaoui, post-graduate student, doualaoui@gmail.com, ORCID: 0000-0001-8113-3822

${ }^{1}$ Odessa State Academy of Civil Engineering and Architecture 4, Didrichson street, Odessa, 65029, Ukraine

\begin{abstract}
There are aspects of scientific research in the analysis of scientific research in the formation of systems of lighting in architecture: energy conservation, shaping in the internal and external space of architecture, integration, technology, aesthetics and innovation. Buildings and cities were designed and oriented according to specific natural and climatic conditions. When designing public and residential buildings, the main focus was on the orientation of their courtyards relative to the sides of the horizon. According to such compositional techniques, the architectural volumes were designed from the south side of the courtyard, orienting and opening them to the north side. This provided both protection from direct solar radiation and the ability to capture cool northerly winds. A similar approach took place then throughout the entire period of medieval architecture in the Arab countries, where the common areas are oriented to the north. Among the totality of studies of insolation problem and sun protection in architecture, a number of areas stand out: aesthetic, analytical, theoretical, experimental, instrumental, biological and hygienic. For the first time in domestic and foreign science in the 80s of the XX century, the problem of improving the quality of modern architecture is determined by natural and artificial lighting in the main categories (expressiveness, comfort, efficiency). Health-improving and sanitizing effects were of great practical importance in the design of modern buildings. Natural and climatic factors have an important impact on the main categories of architecture quality. The main place is occupied by solar radiation and insolation. The term "insolation" means the total solar irradiation and not only direct, but also reflected and scattered over a certain calculated area, which takes into account the combination of light, ultraviolet and thermal effects of the Sun.
\end{abstract}

Keywords: architecture, lighting means, energy conservation, public and residential buildings, insolation.

Statement of the problem and its connection with important scientific and practical problems. In the XX century the rapid development of cities and the need to increase the building density leads to the constant activation of the architectural and urban planning role of the insolation factor: 1) at the beginning of the 20th century, the German architect V. Gropius used only one factor to justify the intervals between ten-story buildings in line buildings - the angle of incidence of the sun's rays; 2 ) in the middle of the 20th century, the Polish architect M. Tvarovsky already used two factors the angle of incidence of the sun's rays and the orientation (deviation of the longitudinal axes of the building from the north-south direction), which make it possible to establish that when the building is moved from the meridian to latitude with the same three-hour insolation, the intervals between the longitudinal facades decrease from 1.7 to $1.1 ; 3$ ) in the $80 \mathrm{~s}$, the benefits of minimal gaps between latitudinal and diagonal buildings become even more evident. According to the research of the professor of the Moscow Institute of Architecture Obolenskiy M.V. who determined the most complete 
picture of insolation of residential buildings using three factors - the angle of incidence of sunlight, the orientation of the window and the geographical latitude of the construction area [1, p. 45-47]. Obolenskiy M.V. classified architectural and planning methods, constructive and technical means of sun protection and light regulation [1, p. 125-128].

Analysis of recent research and publications. Dashkevich L.L. in his monograph devoted to insolation in construction, cites the results of research on scattered radiation, in the biological sense of natural light plays no less role than direct radiation. Only with the help of it, the illumination in all places - where direct sunlight does not directly fall - is achieved. In addition to that, under natural conditions, solar radiation is never only direct.

His monograph Obolensky N.V. is devoted to the physical, mathematical, sociological, and economical, aesthetic justification for the regulation and design of insolation and sun protection of buildings. He formulates one of the urgent problems of improving the quality of modern architecture. Solar radiation is determined according to the main categories: comfort, expressiveness, efficiency. Historical and modern trends in the development of the problem of insolation and sun protection in architecture are analyzed. The meaning of his scientific work is aimed at the further development of one of the most important branches of modern science - architectural ecology [1, p. 4].

The architectural and artistic role of artificial lighting in the architecture of the interior of public and residential buildings was determined by A.S. Shchipanov and A.V. Krivenko.

Fundamental studies of the bactericidal effect of sunlight were carried out by scientists: K. Belikova, N. Danzig, R. Dmitrieva and A. Zabaluev. The author D.N. Lazarev of the idea of "heavenly baths" (comfortable ultraviolet irradiation of a person with natural diffused light from a clear sky). A. Voeikov investigated the influential role of the Sun in the formation of a comfortable architectural environment for humans. Swedish scientists (G. Pleyzhel, H. Rong, L. Holm) studied the influence of insolation on the indoor microclimate. The psychological role of insolation, using calculation methods with the help of "solar charts", was investigated by I. Krokhman and employees of the research institute in Kiel. According to their observations, by heating the walls with the rays of the Sun, it is possible to save up to $80 \%$ of fuel. In England, lighting engineers E. Neeman and R. Hopkinson developed a scale of psychological reactions to indoor insolation conditions.

The aspect of the formation of complex solar protection can be represented by the works of several Ukrainian and foreign design institutes and organizations studying the problems of effective sun-protection residential buildings, depending on the radiation regimes in different regions of the world (Ukrainian Research Institute of Building Physics, a specialized committee on insolation standards under the Ministry of Construction Japan, Research Institute in Kiel, Institute of Light in Stuttgart (Germany) The problem of lighting and microclimate control in buildings with free interior space (atrium types of public complexes, office buildings, hotels, commercial buildings) was comprehensively studied by Richard Saxon (USA) [2].

This concept, first implemented in the project of the administrative building "Scandinavian Airlines" ("SAS", 1987, Stockholm, architect N. Thorp) (Fig. 1), then in the building "Kovcheg" (1987, London, architect R. Erskine), is today reflected in projects of high-rise buildings, such as the "European Central Bank" (2010, Frankfurt am Main, architect bureau "Kup Himmelblau") with a linear atrium uniting two high-rise volumes of the building (Fig. 2); an atrium attached to the high-rise volume of the building "Administrative and public center of the Moscow region" (2008, Moscow, architect M. Khazanov) (Fig. 3) [3].

The atrium in the building of the "European Central Bank" is oriented along the east-west axis in order to maximize the amount of sunlight and natural light. Here, the buffer space of the atrium functions as a "Vertical City", in which a kind of "micro-city" with squares, bridges and crossings is created with the help of connecting platforms located at different levels. The atrium building is a giant double-glazed version. This building provides natural light, protects against bad weather, reduces operating costs and increases the level of comfort [2, p. 6, 7].

In 1986, two of the most high-tech office skyscrapers with atriums wer e built. The atrium in the "Lloyds Building" in London by architect R. Rogers forms a courtyard illuminated from above by a translucent arched vault (Fig. 4). In the building of the "Hong Kong-Shanghai Bank" by architect N. 
Foster there is an open-type atrium, i.e., illuminated from both sides, it is located at the level of the 10 lower floors (Fig. 5, Fig. 6).

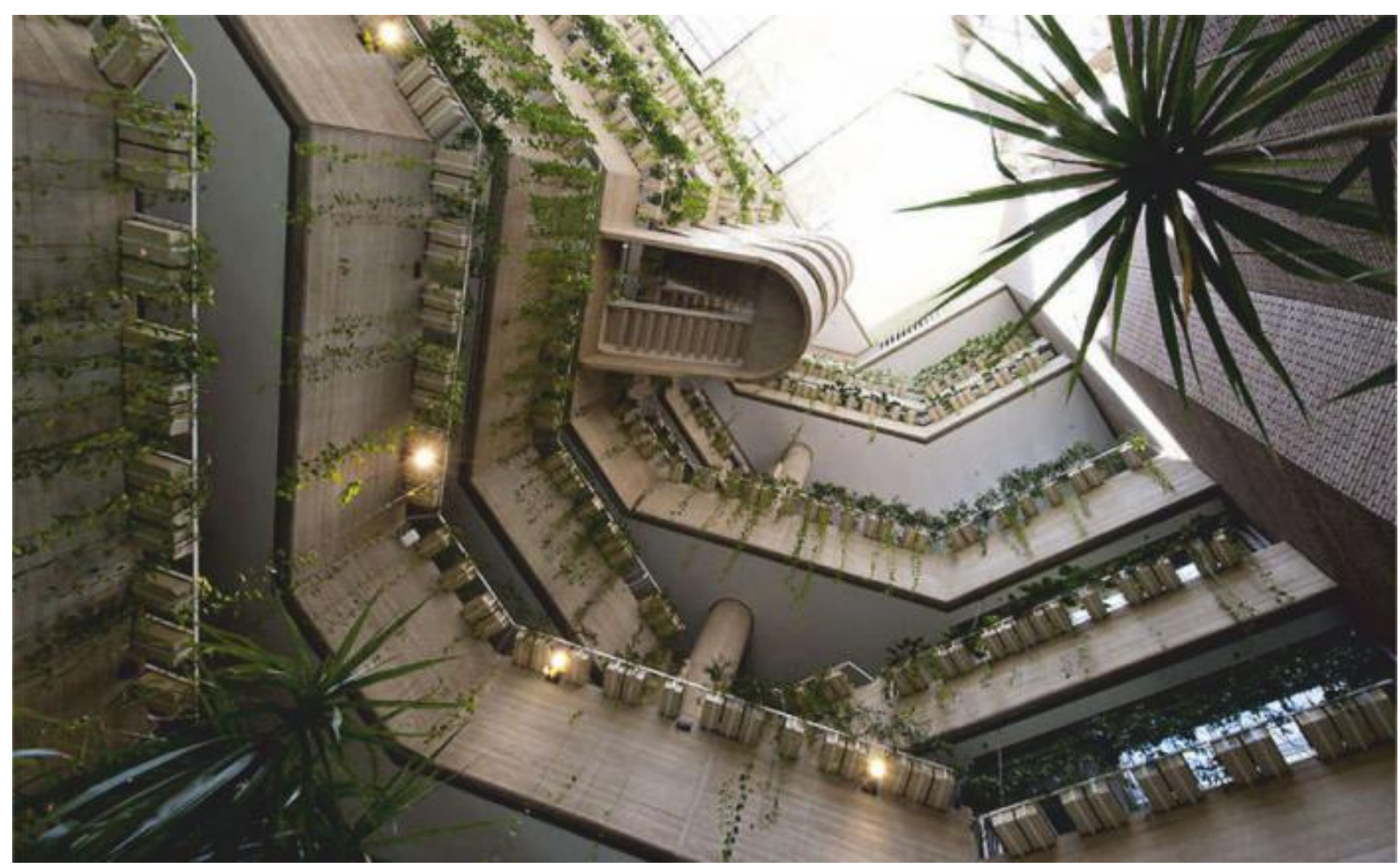

Fig. 1. Atrium in the office building of "Scandinavian Airlines" 1987, Stockholm, architect. N. Thorp

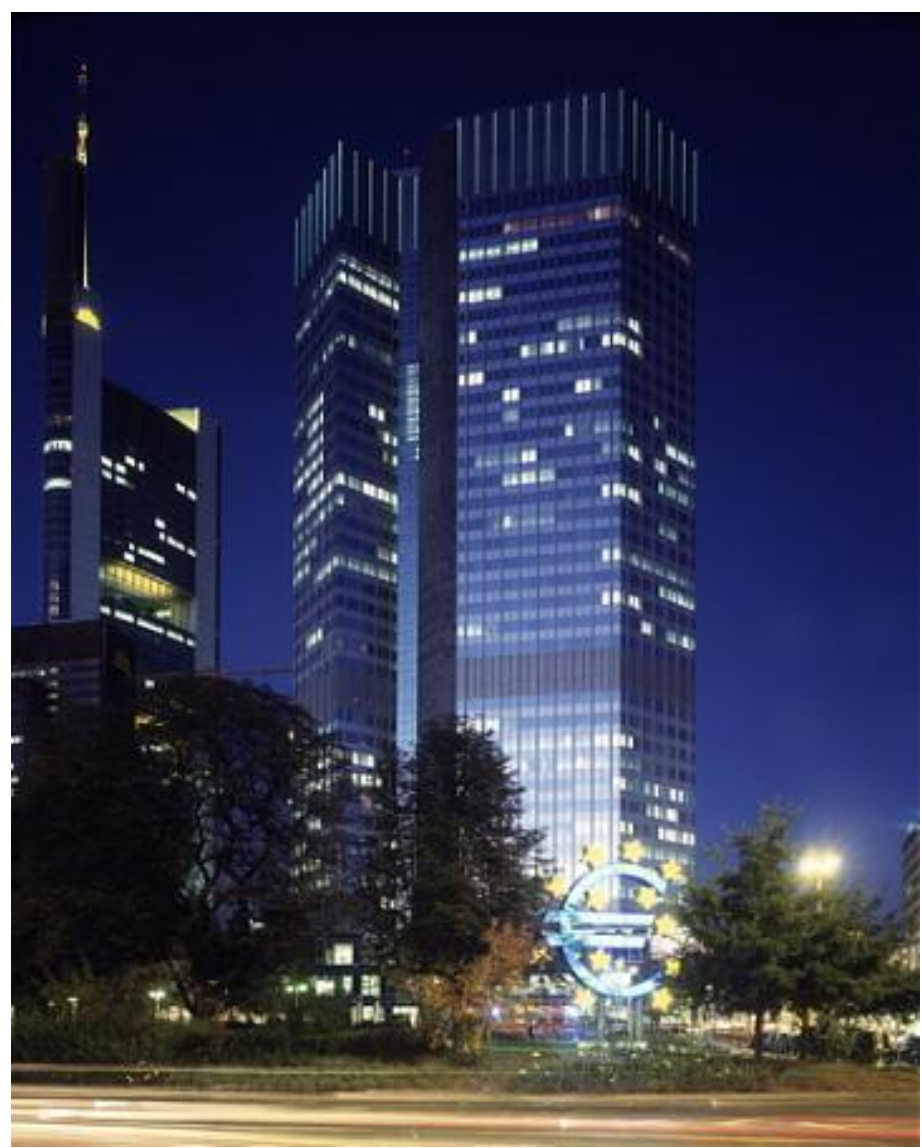

Fig. 2. European Central Bank building project 2010, Frankfurt am Main, arch. Bureau "Koop Himmelblau" 


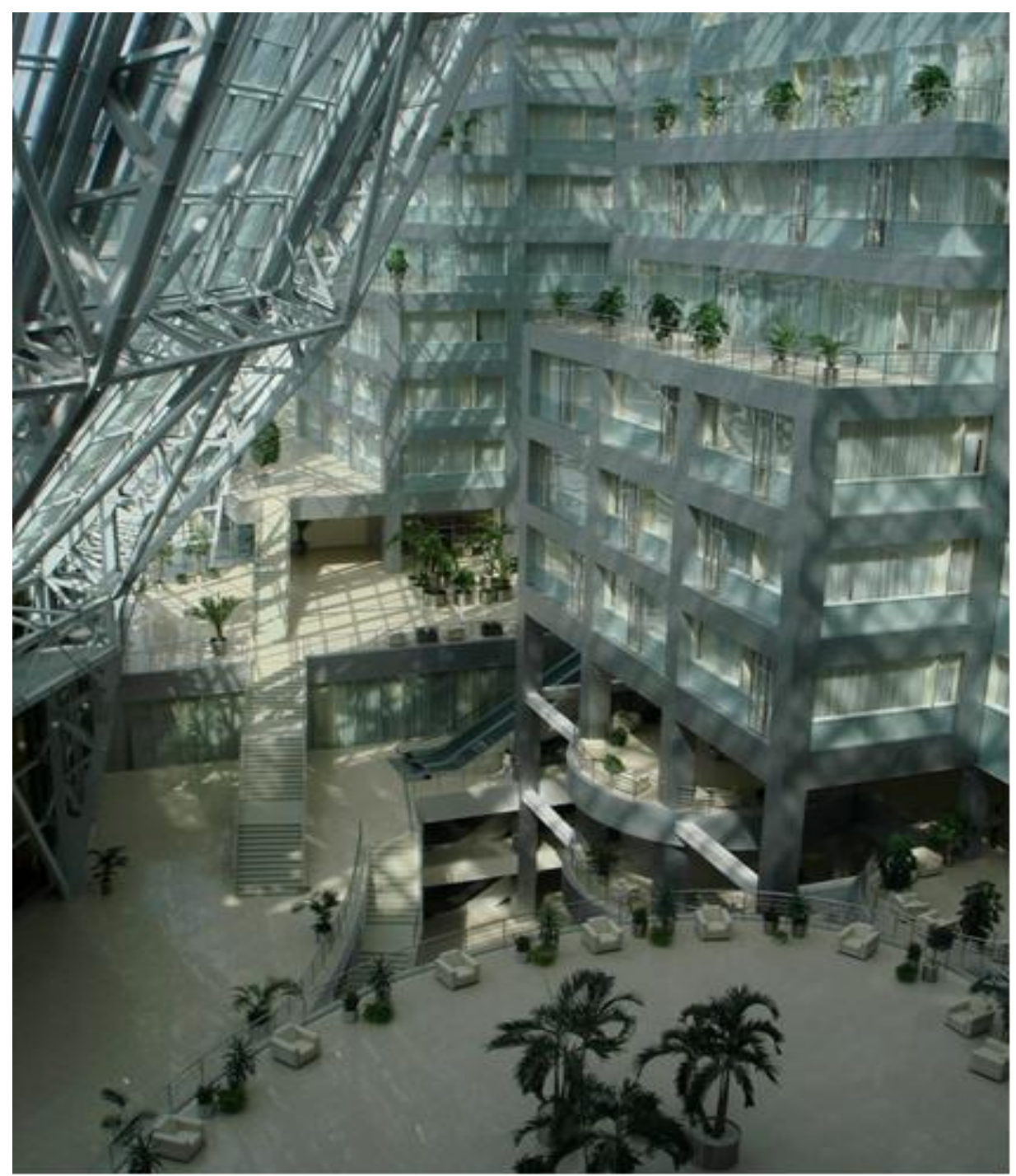

Fig. 3. Atrium in the building of the Administrative and Public Center, 2008, architect. M. Khazanov

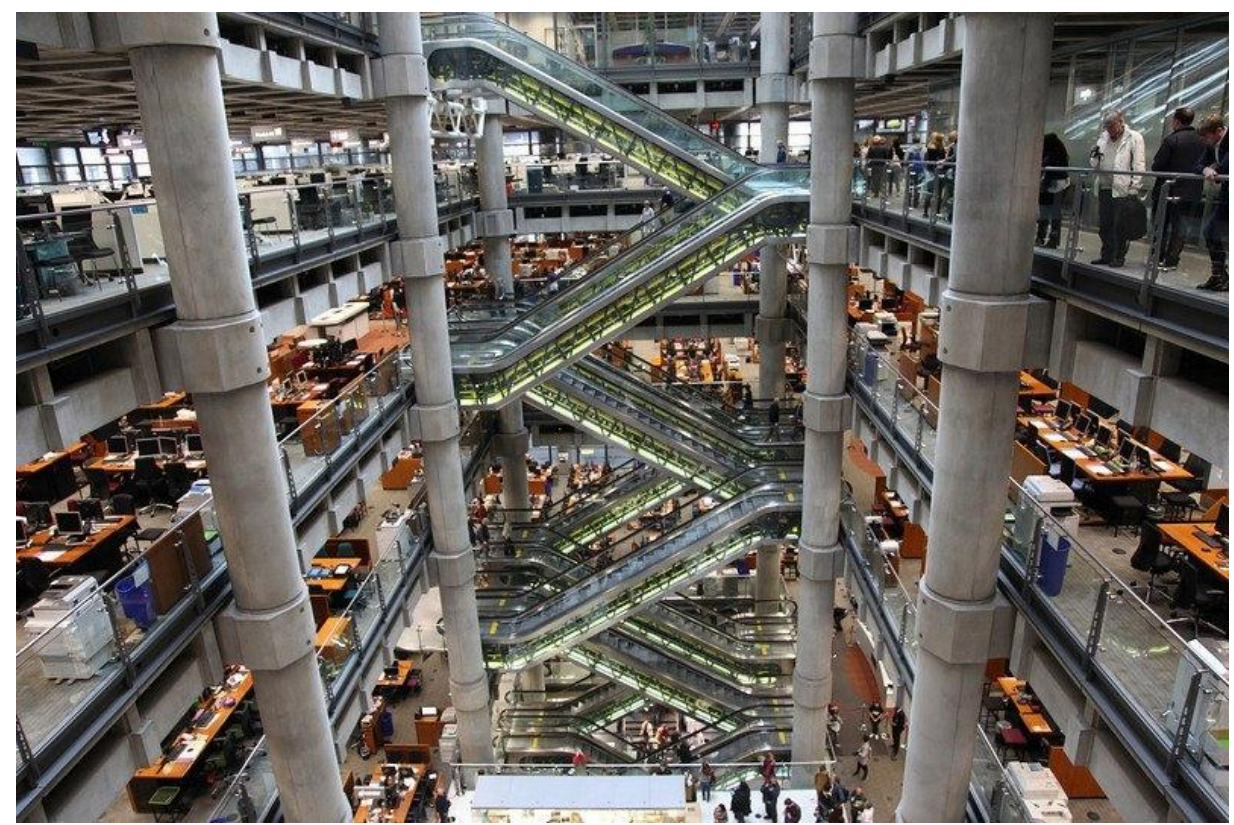

Fig. 4. Atrium in the building of the insurance company "Lloyd" in London, 1987, architect. R. Rogers 


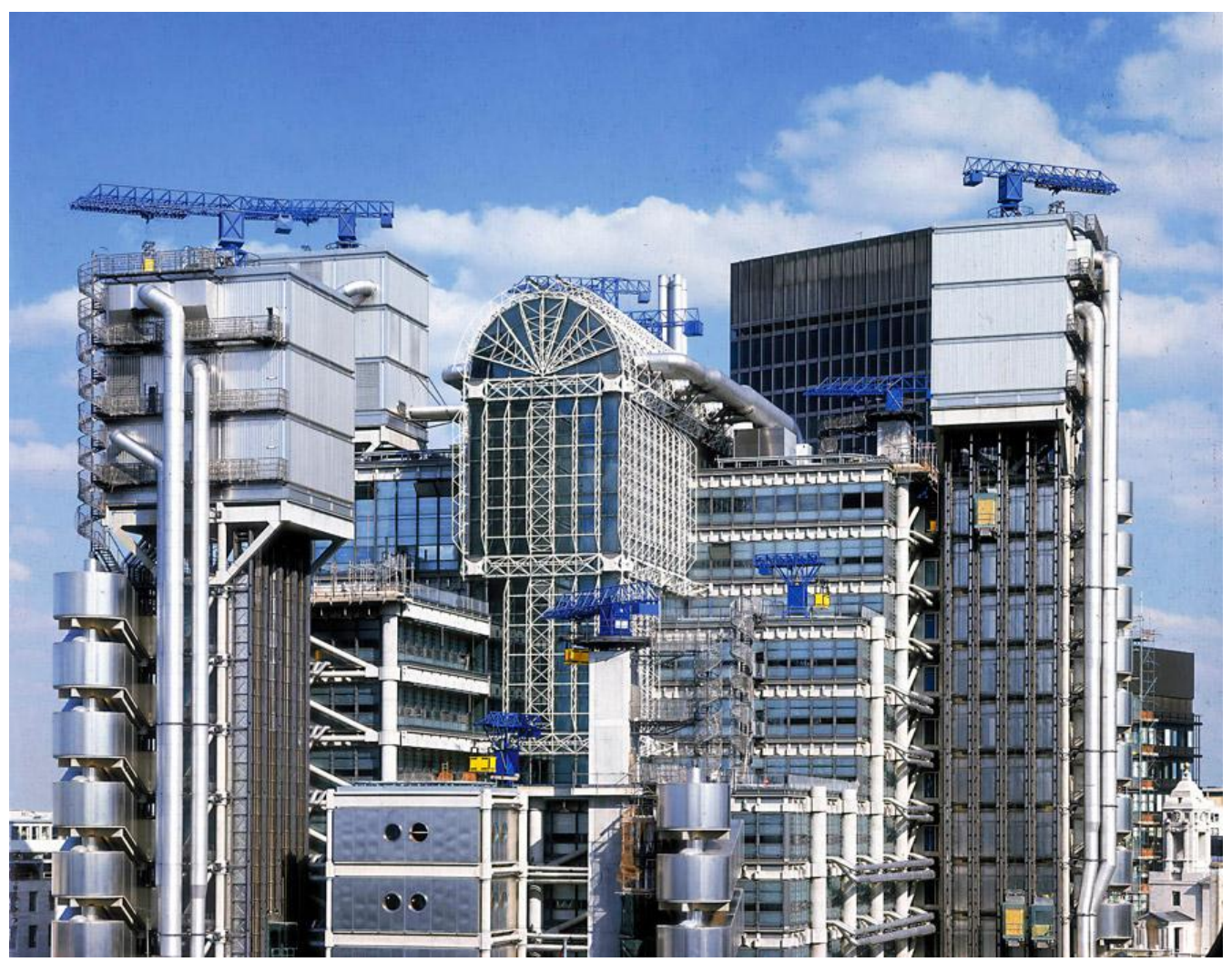

Fig. 5. The building of the insurance company "Lloyd" in London, 1987, architect. R. Rogers
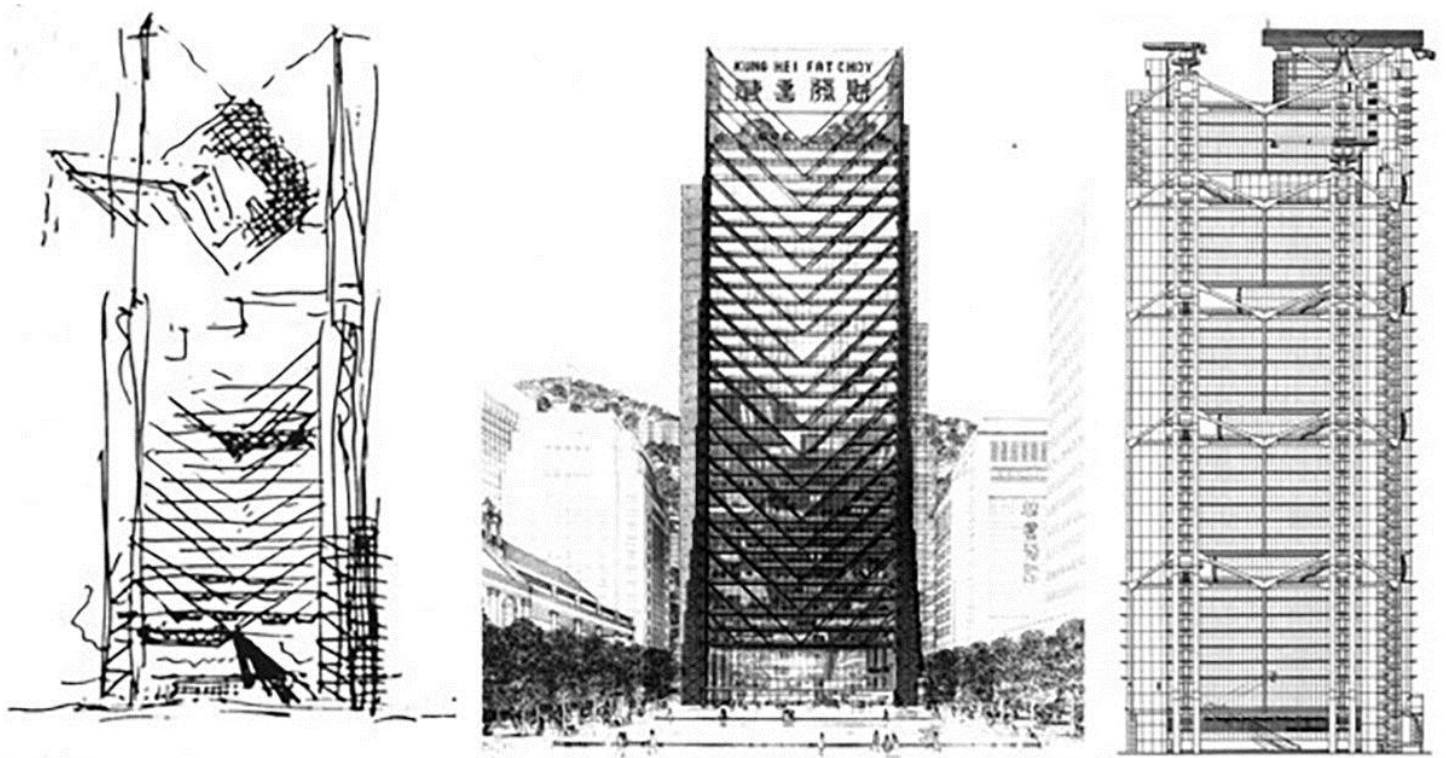

Fig. 6. Hong Kong-Shanghai Bank in Hong Kong, 1987, architect. N. Foster

The advantage of the frame-trunk system made of steel structures placed on the façade in these buildings was the possibility of organizing elevator shafts, staircases and some engineering systems at the outer walls. The space on the lower floors in the middle of the building, freed from supporting structures and columns, turned into a huge courtyard, illuminating deep office spaces. It made possible increasing the width of the high-rise building body and increasing the flexibility and transformability of the functional-planning structure of the skyscraper, creating large workspaces illuminated with natural light, which made it possible to reduce the cost of artificial lighting and air conditioning. 
The purpose of the study. Identification of the main factors of energy saving - as a priority direction of state policy in Ukraine and in the world (problems of using solar energy in architecture).

\section{This goal implies the need to solve the following tasks:}

- based on the analysis of theoretical studies and modern architectural domestic and foreign practice, to identify the main characteristics of the complex of lighting means in the architecture of residential and public buildings;

- relying on modern methodological approaches to improve the methodological basis for the study of a complex of lighting means in the architecture of residential and public buildings;

- to determine the factors of influence of the "light component" on the morphology of the architectural form and the environmental impact of light means on a person in the interior and exterior.

The main research material. Since the second half of the 20th century, urban planning projections are associated with the search for new settlement systems in futurological cities of a new type (a new city, a hanging spatial city, a city with an artificial climate, aquapolis, cosmopolis). Urban trends that have arisen: metabolism (K. Kurokawa), arcology (P. Soleri), automatically regulated architectural systems (Yu. Lebedev, A. Mutnyakovich), urbanism, architectural bionics are based on the biological processes of human shaping. For example, with a change in solar illumination due to aerostatic systems that are automatically controlled, the residential module of a tourist town can change.

The problems of using solar radiant energy in architecture, new systems of principles and methods for improving helio-architectural objects, based on the widespread use of historical experience and V. Kazakov considers folk traditions, bionic analogies and modern scientific and technical achievements, in the monograph.

Currently, there is a limited amount of light energy resources, therefore, the responsibility of architects to ensure visual comfort with minimal energy costs in the designed buildings is increasing. The external structures of the building should effectively combine all design parameters (planning, construction, thermal, light conditions, comfort and technological functions) with the capital and operating costs used (E. Harkness, M. Mehta).

The aesthetic and innovative aspect is associated with the analysis of methods and means of all types of lighting in the formation of the architectural environment.

The main goals and objectives of architectural artificial lighting (urban spaces and individual objects) and methods of their implementation based on the proposed light-compositional system were formulated by M.I. Shchepetkov. He considered the problem of light design of the city in a complex of basic components in the macro-, meso- and micro-scale of the human environment. He transforms this scientific and creative problem from a purely engineering one into an architecturalurbanistic and light-design one and considers it as a new branch of the professional activity of architects and designers in the formation of the evening visual environment of the city.

In the field of research on the formative role of color in architecture, the perception of which is directly related to the effect of sunlight, experiments were carried out by A.V. Efimov (Moscow, Russia), V.I. Portnoy and N.E. Tregub (Kharkov, Ukraine). In particular, V.I. Portnoy determined the quantitative indicators of the coloristic component of the architectural form.

In recent decades, famous architects N. Foster, R. Rogers, J. Nouvel, B. Chumi, K. Portzamparc, F. Gary, R. Meyer, T. Ito, and T. Ando created original light images of their structures in collaboration with light - designers. Le Corbusier offers forecasts - city lighting through the synthesis of architecture, painting and electrical engineering will turn into a direction of new art and lighting will lead to new conclusions in the field of architecture and planning.

The analysis of previous scientific studies (monographs, dissertations, textbooks, articles), which are devoted to the genesis, development and existing architectural and urban planning methods of solving the problem of forming an optimal architectural light regime for life, for various natural and climatic conditions and regions of the Earth, made it possible to identify the world trends and practical recommendations for the design of "light architecture". Trends that have emerged today: the concept of creating an "intermediate space" in architecture, which performs specific buffer functions of the zone between the interior and the outer space (K. Kurokawa), the principle of compact placement of the entire population in one "closed space" like a large artificial oasis. A giant tent in the form of a lens 
covers this object with installed solar generators (P. Maimon) the idea of a complex penetration of light into the building through "back windows", wall screens (Louis Kahn).

A critical analysis of foreign architectural practice showed that, despite the developed options for sunscreens, starting from the 1920s, not all famous masters of architecture, such as Mies van der Rohe and Oscar Niemeyer, proposed architectural forms in their designs that due to the solution of problems of regulation of solar radiation. Scientists considered sunlight, first of all, as an aesthetic factor and tried to apply sun protection in architecture mainly as a character of decoration.

In modern architecture of the 20th century, five compositional sun-screening techniques have been proposed, which should be considered ineffective (non-functional):

1) use as sun-protection heavy concrete screens and canopies, monolithically connected to the supporting structures of buildings, which accumulate solar energy and then transform it into long-wave heat, which is additionally supplied to the room; 2) inconsistency of the geometric parameters of the shading required for the shading conditions of the light openings; 3 ) the use of sun protection devices (in order to protect against overheating) on the inside of the skylights; due to the well-known "greenhouse effect" in physics (solar radiation that has passed through the glazing is transformed in the room into long-wave radiant heat, heating the inner surfaces and objects); 4) the use of sun protection in the form of plastic - inherent in the architecture of tropical countries, in buildings that are being built in the central and northern regions; application of the same appearance of sun protection on all facades of the building without taking into account its orientation and justification of the urban planning composition; 5) modern types of solar control glass do not provide protection against light and thermal discomfort. Glass, reflects heat, is partially effective in reducing overheating and is not an effective remedy against the glare of direct sunlight (Firsanov V.M., Harkness E., Mehta M.).

As the analysis of literary sources has shown, in the context of the peculiarities of the national climatological architecture, the architectural-planning and spatial organization of residential and public buildings, the regions of the Arab-Islamic countries are the most researched today. The authors, who, in their scientific studies, fragmentarily dealt with the problem of comfortable living conditions in the countries of the Arab East, are as follows: Mahmoud Salman Yousef, Younes Hassan Ali, Salah Ahmed, Tunsy Shaker, Nasif Makki Mohammad Ghanem. The scientific work of Mahmoud Ali Hassan Al Subekh [4] is devoted to the actual problem of the urban ecological approach in the architectural shaping of the environment.

Climate-forming factors develop and are detailed by the characteristics of climatic-ecological models of spaces, including: solar maps; annual variations of average monthly outdoor air temperatures, their average maximum and average minimum values; relative humidity; wind speed and direction; precipitation; the number of hours of sunshine per day. Further, on the basis of parameters that are comfortable for a person - the microclimate in buildings and the microenvironment in the premises of housing, the boundary conditions of the types of weather, temperature, humidity and air mobility - the types are calculated and determined: weather conditions of the regions; weather characteristics and their duration; the nature of the person's connection with the living environment; typological requirements for their formation. They are supplemented by data on the ecological state of the environment in relation to the sectors and directions of their impact on humans.

According to the work of Younes Ali Hasan (1991), according to the proposed norms, the ratio of the light areas of window openings to the areas of the floor of the interior space should be in the range of 1:1.5-1:2.0.

When placing groups of rooms around a courtyard-garden, the layout of the building becomes "closed", which provides reliable protection against excessive insolation, high temperatures, overheating and penetration of dust and sand. The proportions of the planning schemes: 1:1; 1:1.8. In a hot-humid climate (the western design and construction region of the country Al-Sham), "open" architectural and compositional structures of buildings are recommended - a narrow long parallelepiped with proportions of 1:3, the optimal solution is 1:1.7 (Firsanova V.M.) [5]. In both variants of compositional solutions, the longitudinal walls of buildings should be oriented to the north and south (with the longitudinal axes of the building - west-east). Such sun-protection elements as visors, galleries, loggias, iwans, and ventilated roofs are of great importance in the formation of the architectural and artistic image of buildings in hot climates. 
The effect of insolation on humans and the environment is twofold: on the one hand, it is beneficial and economically beneficial, therefore it is necessary to ensure access of sunlight to urban spaces and interiors of buildings in any geographic area, on the other, it can cause overheating, light discomfort, ultraviolet irradiation, and excessive consumption of electricity for microclimate control. These complex contradictions between the positive and negative aspects of the influence of insolation are in dialectical unity (Table 1).

Table 1 - The unity of the positive and negative effects of insolation in architecture (N.V. Obolensky, 1988)

\begin{tabular}{|c|c|c|}
\hline $\begin{array}{c}\text { Aspects of } \\
\text { the influence } \\
\text { of insolation }\end{array}$ & Positive effects & Negative effects \\
\hline Biological & General health effect & City gas toxicity, light discomfort \\
\hline Psychological & $\begin{array}{c}\text { "Sunshine" lighting, dynamics of the } \\
\text { distribution of brightness and } \\
\text { chromaticity in the field of view, } \\
\text { connection with the surrounding space }\end{array}$ & $\begin{array}{c}\text { Decreased activity and mood with } \\
\text { light discomfort and overheating }\end{array}$ \\
\hline Aesthetic & $\begin{array}{c}\text { Revealing space, form, plastics, } \\
\text { silhouette and light ratios, rhythm of } \\
\text { elements of architecture and "painting", } \\
\text { compositional solutions }\end{array}$ & $\begin{array}{c}\text { Decreased shape perception and color } \\
\text { saturation from excessive brightness }\end{array}$ \\
\hline Economic & $\begin{array}{c}\text { A natural source of additional heating } \\
\text { of premises, a reduction in the area of } \\
\text { light openings, an increase in labor } \\
\text { productivity }\end{array}$ & $\begin{array}{c}\text { Increased costs for ventilation and air } \\
\text { conditioning, decreased labor } \\
\text { productivity with thermal and light } \\
\text { discomfort }\end{array}$ \\
\hline
\end{tabular}

Based on fundamental research, N.V. Obolensky, who classified the aspects of the influence of insolation (biological, psychological, aesthetic and economic) and systematized the main indicators of the quality of architecture in different climatic zones: in the zone of solar "deficit", in the zone of "comfort" and in the zone of "Hyper-insolation" (Table 2.).

Table 2 - The main indicators of the quality of architecture in different climatic zones (for N.V. Obolensky, 1988)

\begin{tabular}{|c|c|c|c|}
\hline $\begin{array}{c}\text { Construction quality } \\
\text { indicators }\end{array}$ & $\begin{array}{c}\text { I zone } \\
\text { Solar deficiency }\end{array}$ & III comfort zone & V zone of hyperinsolation \\
\hline $\begin{array}{c}\text { Comfortable } \\
\text { environment }\end{array}$ & $\begin{array}{c}\text { Ensuring insolation } \\
\text { during the light } \\
\text { season, cold, moisture, } \\
\text { wind, snow, and light } \\
\text { protection }\end{array}$ & $\begin{array}{c}\text { Providing } \\
\text { insolation for 10 } \\
\text { months, cold and } \\
\text { moisture protection }\end{array}$ & $\begin{array}{c}\text { Provision of insolation } \\
\text { for 6 months. } \\
\text { Heat moisture protection }\end{array}$ \\
\hline $\begin{array}{c}\text { Reliability of } \\
\text { structures and } \\
\text { materials }\end{array}$ & $\begin{array}{c}\text { Moisture and cold } \\
\text { resistance }\end{array}$ & Moisture resistance & Heat light fastness \\
\hline $\begin{array}{c}\text { Expressiveness of } \\
\text { space and form. }\end{array}$ & $\begin{array}{c}\text { Deficiency of } \\
\text { "specificity of the } \\
\text { architectural image }\end{array}$ & Plastic walls & Plastic light openings \\
\hline $\begin{array}{c}\text { Cost-effective design } \\
\text { solutions }\end{array}$ & Building density & Building density & Building density \\
\hline
\end{tabular}


For the zone of solar deficiency, the comfort of the environment is achieved by ensuring insolation during the daytime (by means of cold, moisture, wind, snow and light protection). In the comfort zone, favorable environmental conditions are provided by insolation for 10 months (by means of cold protection and moisture protection), in the hyper-insolation zone, the comfort of the environment is achieved by ensuring insolation for six months (by means of heat protection and moisture protection), for this zone there are important indicators of heat resistance and light resistance of structures and materials. To achieve expressiveness of space and forms, as well as a specific architectural image for the zone of solar deficit, it is necessary to compensate for the deficit of "sunshine". In the comfort zone, an important compositional means is the "plastic walls", and for the zone of hyper-insolation - the "plastic light openings".

The integral criterion (functional comfort) is considered as the optimal functional state, at which the compliance of the means and environmental conditions of human activity is achieved. As a systemic education, functional comfort includes two basic components - psychological and physiological. It is characterized by pleasure in activity, as well as high efficiency. A comfortable architectural light environment is a system that provides functional comfort in the interior, which is accompanied by visual and aesthetic comfort in the exterior environment [6].

The presence of spots with brightness in the field of view that significantly exceeds the brightness of adaptation can cause unpleasant sensations called discomfort. The International Commission on Lighting defines visual discomfort as a feeling of tension. An indicator of discomfort serves as a quantitative characteristic. The second quantitative assessment is reduced to determining the value of brightness, which lies on the border of comfort - discomfort [7].

Obolensky N.V. notes that often a continuous 3-hour insolation of buildings and territories leads to thermal discomfort not only in the southern, but also in the central regions of the country, as well as to light discomfort in all geographic regions [1, p. 15].

Shchepetkov M.I. considers the light component to be an important part of the architectural environment, the objective basis of its artistic image, and artificial light as an effective and mobile means of transforming it. "It allows for artistic and practical purposes to instantly carry out the visual transformation of the plane, volume, space in chamber and "cosmic" scales" [8].

Conclusions. There is a complex and multifaceted relationship between the radiant energy of the Sun and architecture. As a result of the systematization and generalization of the theoretical provisions put forward by the authors of previous studies. The issue of energy saving is analyzed as a priority direction of state policy in Ukraine and in the world. A hierarchical scheme-model of the relationship of the components and functions of natural and artificial light with elements of the architectural environment is proposed. The light environment of architectural objects contains four levels:

- 1st "micro" structural level - light environment of the interior, work areas, workplace, room, group of rooms;

- 2nd "meso" structural level - the light environment of residential and public buildings and building complexes;

The light environment of urbanized areas contains:

- 3rd "macro" structural level (space of a street, block, district);

- 4th "hyper" structural level (urban landscape complexes).

Generalization and systematization of the research results obtained by predecessors and world architectural practice made it possible to identify a number of unresolved issues related to the problem of forming the methodological foundations of a complex of lighting means in the architecture of residential and public buildings, became the object and subject of this study, as well as the basis for determining the goals, objectives and prospects for further development in this direction of research.

\section{References}

[1] V.K Licekevich, L.I. Makrintnko, I.V. Migalina i dr., Architerturnaja fizika: Spec. Architertura. Pod red. N.V. Obolenskoho, M.: «Architertura-C». 2007. 
[2] K.A. Andrianov, L.I. Matveev, A.M. Makarov, Stroitelnaja fizyka: uchebnoe posobie. Tambov, 2007.

[3] Gordina Elena ZHanovna, "Atriumnye prostranstva v vysotnyh zdaniyah. Etapy razvitiya". [Online]. Available: https://cyberpedia.su/10xa034.html. Accessed on: May 10, 2021.

[4] A.J. Bogatina, A.A. Revakin, Architerturnaja svetologija i stroitelnaja svetotechnika: uchebnoje posobie. Rostov na Donu, 2010.

[5] V.K. Savin, Stroitelnaja fizika: M.: Lazur, 2005.

[6] O.I. Lesnaja, Dekorativno-hudozestvennoe osveshchenije architekturnoj sredy: uchebnoje posobie. Harkov, 2008.

[7] A. Vasilenko, A. Koniuk, "Light Facilities Complex in Architectural Design", Proceedings of the 2nd International Conference on Building Innovations ICBI 2019. Springer. Lecture Notes in Civil Engineering, vol. 73, pp. 491-590, 2019.

[8] N.I. Shchepetkov, Svetovoj dizajn goroda. M.: Architektura, 2006.

\title{
ЕНЕРГОЗБЕРЕЖЕННЯ - ЯК ПРІОРИТЕТНИЙ НАПРЯМОК ДЕРЖАВНОЇ ПОЛІТИКИ В УКРАЇНІ ТА СВІТІ: ПРОБЛЕМИ ВИКОРИСТАННЯ СОНЯЧНОЇ ЕНЕРГІЇ В АРХІТЕКТУРІ
}

\author{
${ }^{1}$ Єрмакова С.C., д. пед. наук, професор, \\ ermakova.s2011@yandex.ua, ORCID: 0000-0001-9524-518X \\ ${ }^{1}$ Василенко О.Б., д. арх, професор, \\ abvasilenko10@gmail.com, ORCID: 0000-0002-8261-3104 \\ 1Эль Ешеих Эль Алауі Дуаа, аспірант \\ doualaoui@gmail.com ORCID: 0000-0001-8113-3822 \\ ${ }^{1}$ Одеська державна академія будівництва та архітектури \\ вул. Дідріхсона, 4, м. Одеса, 65029, Україна
}

\begin{abstract}
Анотація. В аналізі наукових досліджень при формуванні систем світлових засобів в архітектурі мають місце аспекти наукового дослідження: енергозбереження, формоутворення у внутрішньому і зовнішньому просторі архітектури, інтеграція, технологія, естетика, інновація. Будівлі й міста проектувалися і були орієнтовані з урахуванням конкретних природних і кліматичних умов. При проектуванні громадських і житлових будівель основна увага була направлена на орієнтацію їх внутрішніх двориків щодо сторін горизонту. Згідно з такими композиційним прийомам архітектурні обсяги проектували 3 південного боку двору, орієнтуючи i розкриваючи їх на північну сторону. Цим забезпечувалось одночасно захист від прямої сонячної радіації і можливості отримувати прохолодні північні вітри. Аналогічний підхід мав місце потім протягом всього періоду середньовічної архітектури арабських країн, де загальні приміщення орієнтовані на північ. Серед сукупності досліджень проблеми інсоляції і сонцезахисту в архітектурі виділяється ряд напрямків: естетичний, аналітичний, теоретичний, експериментальний, інструментальний, біологічний, гігієнічний. Вперше у вітчизняній і зарубіжній науковій практиці в 80-ті роки XX ст. проблема підвищення якості сучасної архітектури, визначається природним і штучним освітленням за основними категоріями (виразності, комфортності, економічності). Велике практичне значення в проектуванні сучасних будівель мали оздоровчі ефекти. Природні і кліматичні чинники надають не останній вплив на основні категорії якості архітектури. Основне місце займає сонячна радіація і інсоляція. Під терміном «інсоляція» розуміють сумарне сонячне опромінення і не тільки пряме і відбите, а й розсіяне на певній розрахунковій площі, де враховується сукупність світлового, ультрафіолетового та теплового впливу Сонця.

Ключові слова: архітектура, світлові засоби, енергозбереження, громадські і житлові будівлі, інсоляція.
\end{abstract}




\title{
ЭНЕРГОСБЕРЕЖЕНИЕ - В КАЧЕСТВЕ ПРИОРИТЕТНОГО НАПРАВЛЕНИЯ ГОСУДАРСТВЕННОЙ ПОЛИТИКИ В УКРАИНЕ И В МИРЕ: ПРОБЛЕМЫ ИСПОЛЬЗОВАНИЯ СОЛНЕЧНОЙ ЭНЕРГИИ В АРХИТЕКТУРЕ
}

\author{
${ }^{1}$ Ермакова С.С., д.пед.наук, профессор, \\ ermakova.s2011@yandex.ua, ORCID: 0000-0001-9524-518X \\ ${ }^{1}$ Василенко А.Б., д. арх., профессор, \\ abvasilenko10@gmail.com, ORCID: 0000-0002-8261-3104 \\ 1Эль Ешеих Эль Алауи Дуаа, аспирант, \\ doualaoui@gmail.com, ORCID: 0000-0001-8113-3822 \\ ${ }_{1}^{1}$ Одесская государственная академия строительства и архитектуры \\ ул. Дидрихсона, 4, г. Одесса, 65029, Украина
}

\begin{abstract}
Аннотация. В анализе научных исследований при формировании систем световых средств в архитектуре имеют место аспекты научного исследования: сбережение энергии, формообразование во внутреннем и наружном пространстве архитектуры, интеграция, технология, эстетика, инновация. Здания и города проектировались и были ориентированы с учетом конкретных природных и климатических условий. При проектировании общественных и жилых зданий основное внимание обращалось на ориентацию их внутренних двориков относительно сторон горизонта. Согласно таким композиционным приемам архитектурные объемы проектировали с южной стороны двора, ориентируя и раскрывая их на северную сторону. Этим обеспечивали одновременно защиту от прямой солнечной радиации и возможности улавливания прохладных северных ветров. Аналогичный подход имел место затем в течение всего периода средневековой архитектуры арабских стран, где общие помещения ориентированы на север. Среди совокупности исследований проблемы инсоляции и солнцезащиты в архитектуре выделяется ряд направлений: эстетический, аналитический, теоретический, экспериментальный, инструментальный, биологический, гигиенический. Впервые в отечественной и зарубежной науке в 80-е годы XX в. проблема повышения качества современной архитектуры, определяется естественным и искусственным освещением по основным категориям (выразительности, комфортности, экономичности). Большое практическое значение в проектировании современных зданиях имели оздоровительные и санирующие эффекты. Природные и климатические факторы оказывают не последнее влияние на основные категории качества архитектуры. Основное место занимает солнечная радиация и инсоляция. Под термином «инсоляция» понимают суммарное солнечное облучение и не только прямое, но и отраженное, и рассеянное на определенную расчетную площадь, где учитывается совокупность светового, ультрафиолетового и теплового воздействия Солнца.

Ключевые слова: архитектура, световые средства, сбережение энергии, общественные и жилые здания, инсоляция.
\end{abstract}

Стаття надійшла до редакції 15.05.2021 